\title{
Effects of Propionibacteria and Yeast Culture Fed to Steers on Nutrient Intake and Site and Extent of Digestion'
}

\author{
K. V. Lehloenya, ${ }^{*}$ C. R. Krehbiel, ${ }^{*}$ K. J. Mertz,† T. G. Rehberger, † and L. J. Spicer ${ }^{\star 2}$ \\ *Department of Animal Science, Oklahoma State University, Stillwater 74078 \\ †Agtech Products Inc., Waukesha, WI 53186
}

\begin{abstract}
The effects of feeding Propionibacterium strain P169 (P169), yeast culture (XPY), and their combination on nutrient intake, site and extent of digestion, and ruminal kinetics were evaluated in a completely randomized experimental design. Ruminally and duodenally cannulated Angus $\times$ Hereford steers $(\mathrm{n}=12)$ were assigned to 1 of 4 treatments in each of 2 periods: 1 ) control, fed a sorghum silage-based total mixed ration; 2) P169, fed the control plus P169 $\left(6 \times 10^{11} \mathrm{cfu} /\right.$ steer per d); 3) XPY, fed the control plus XPY (56 g/steer per d); and 4) P169 $+\mathrm{XPY}$, fed the control plus P169 and XPY (at $6 \times 10^{11}$ cfu/steer per d and $56 \mathrm{~g} /$ steer per d, respectively). Each period lasted $21 \mathrm{~d}$; d 1 to 15 were used for diet adaptation and d 16 to 21 were used for fecal, duodenal, ruminal, and blood sample collection. Steers were individually housed and fed. Feeding XPY tended to decrease intake of organic matter, acid detergent fiber, and $\mathrm{N}$, and decreased intake of neutral detergent fiber. However, feeding XPY alone tended to increase total tract digestibility of organic matter, $\mathrm{N}$, neutral detergent fiber, and acid detergent fiber. Ruminal digestibility, duodenal flow, microbial $\mathrm{N}$ synthesis, microbial efficiency, and fluid and particulate passage rates were not affected by dietary treatments. Feeding P169 tended to decrease molar proportion of acetate, increased molar proportion of propionate (by $9.7 \%$ ), and tended to decrease acetate:propionate ratio compared with control steers. No other effects of XPY or P169 on ruminal fermentation were observed. Plasma glucose and insulin concentrations were not affected by dietary treatment. Our results suggest that feeding P169 alters ruminal metabolism toward increased propionate without affecting feed intake or ruminal kinetics, whereas feed-
\end{abstract}

\footnotetext{
Received June 22, 2007.

Accepted October 15, 2007.

${ }^{1}$ This work was approved for publication by the Director, Oklahoma Agricultural Experiment Station, and was supported in part under projects H-2510 and a grant from the Kellogg Foundation.

${ }^{2}$ Corresponding author: leon.spicer@okstate.edu
}

ing XPY alone tended to increase total tract digestibilities of nutrients.

Key words: cattle, digestibility, propionibacteria, yeast culture

\section{INTRODUCTION}

Ruminal propionate is the single most important substrate for gluconeogenesis in lactating dairy cows (Drackley et al., 2001). Estimates by Seal and Reynolds (1993) indicate that propionate supplies 32 to $73 \%$ of glucose demands. Both drenching (Grummer et al., 1994) and feeding propylene glycol (Christensen et al., 1997) have increased ruminal propionate and plasma insulin and have decreased blood NEFA concentrations, all of which are beneficial to combating the extent and duration of negative energy balance, fatty liver, and ketosis (Gerloff, 2000; van Knegsel et al., 2005). Effects of propylene glycol are partially mediated through the observed increases in ruminal propionate (Grummer et al., 1994; Christensen et al., 1997), providing a reason to feed propionate substrate during the transition period. Feeding the propionate-producing bacteria Propionibacterium strain 169 (P169) to Holstein dairy cows increased the proportion of ruminal propionate and milk production (Stein et al., 2006), but little evidence exists in the literature regarding the effects of feeding P169 on DMI, digestibility, or microbial CP synthesis.

Yeast and yeast cultures have been fed to dairy cattle for more than $60 \mathrm{yr}$ with varied responses (Schingoethe et al., 2004). In some studies, yeast cultures increased DMI (Wohlt et al., 1991) and milk production (Wang et al., 2001), whereas other studies (Arambel and Kent, 1990; Soder and Holden, 1999) have shown no response to yeast cultures. In vitro experiments have reported that in some cases, Saccharomyces cerevisiae favorably altered the mixed ruminal microorganism fermentation and stimulated lactate uptake and cellulose digestion by pure cultures of predominant bacteria (Callaway and Martin, 1997). Even though the effects of yeast and yeast cultures are not always consistent (Martin and Nisbet, 1992), several modes of action have been proposed regarding their stimulatory effects on ruminal 
fermentation (Wallace, 1994; Beauchemin et al., 2006) and increased milk production (Wohlt et al., 1991).

Recently, Stein et al. (2006) fed P169 in conjunction with yeast culture and reported an $8 \%$ increase in milk production, an increased proportion of ruminal propionate, and an increased percentage of milk protein by Holstein dairy cows compared with control cows. However, it was not determined whether P169 and yeast culture increased the flow of microbial cell protein to the duodenum, spared glucogenic AA, or both to increase milk protein. The objective of the present study was to determine whether yeast culture (XPY), P169, or their combination would improve DMI, the site and extent of digestion, microbial protein synthesis, and ruminal fermentation in mature steers.

\section{MATERIALS AND METHODS}

\section{Animals and Treatments}

This experiment was conducted at the Nutrition Physiology Research Center, Stillwater, Oklahoma, in accordance with an approved Oklahoma State University Animal Care and Use Committee protocol. Twelve ruminally and duodenally cannulated Angus $\times$ Hereford crossbred steers (initial BW $=534 \pm 32 \mathrm{~kg}$ ) were randomly allotted to 1 of 4 treatments ( $\mathrm{n}=3$ steers/ treatment) in a completely randomized experimental design replicated in two 21-d periods. In period 2, steers were reallocated to treatments such that no steer received the same treatment twice. During the experiment, steers were housed in individual indoor pens (3 $\times 4 \mathrm{~m}$ ) with ad libitum access to fresh water. Treatments included 1) a control, in which steers were fed a sorghum silage-based TMR (Table 1); 2) P169, in which steers were fed the control plus P169 $\left(6 \times 10^{11} \mathrm{cfu} /\right.$ steer per d; Agtech Products Inc., Waukesha, WI); 3) XPY, in which steers were fed the control plus Diamond VXP Yeast Culture (Diamond V Mills Inc., Cedar Rapids, IA; 56 g/steer per d); and 4) P169 + XPY, in which steers were fed the control plus P169 and XPY (at $6 \times 10^{11}$ cfu/steer per $\mathrm{d}$ and $56 \mathrm{~g} /$ steer per $\mathrm{d}$, respectively). Yeast culture and P169 were mixed with $4.5 \mathrm{~kg}$ of TMR and fed to steers each morning. Following complete consumption of the $4.5 \mathrm{~kg}$ (approximately $2 \mathrm{~h}$ ), steers were offered additional TMR for ad libitum intake.

During each of the 2 experimental periods, d 1 through 15 were used for diet adaptation and d 16 through 21 were used for sample collection. On $d 1$ of each period, animals were weighed and returned to their respective pens. Ten days before duodenal digesta sampling, gelatin capsules containing $7.5 \mathrm{~g}$ of chromic oxide (indigestible marker) were placed directly in the rumen at 0800 and $1700 \mathrm{~h}(15 \mathrm{~g} /$ steer per d) to enable prediction of duodenal flow and fecal output (Merchen,
Table 1. Ingredient and chemical composition of the basal TMR (DM basis)

\begin{tabular}{lc}
\hline Item & Amount \\
\hline Ingredient, \% (DM basis) & \\
Sorghum silage & 19.6 \\
Alfalfa & 24.5 \\
Grain mix & 47.9 \\
Whole cottonseed & 7.35 \\
Megalac-R ${ }^{1}$ & 0.65 \\
Grain mix, \% of grain mix (DM basis) & \\
Ground corn & 60.7 \\
Wheat middlings & 15.8 \\
Soybean meal & 14.3 \\
Extruded-expeller soybean meal & 5.6 \\
Calcium carbonate & 1.0 \\
Sodium bicarbonate & 1.0 \\
Magnesium oxide & 0.5 \\
Salt & 0.5 \\
Zinpro 4-Plex ${ }^{2}$ & 0.1 \\
Vitamin and trace mineral premix & 3 \\
Chemical composition, ${ }^{4} \%$ & 0.5 \\
DM & \\
CP & 65.2 \\
NDF & 16.7 \\
ADF & 40.6 \\
Ash & 25.5 \\
Ca & 8.10 \\
P & 0.90 \\
\end{tabular}

${ }^{1}$ Church \& Dwight Co. Inc., Princeton, NJ; Megalac-R contains: fat (as fatty acids), $82.5 \%$; Ca, 8.5\%; IOD (moisture), 3 to $4 \%$.

${ }^{2}$ Zinpro Corp., Eden Prairie, MN; Zinpro 4-Plex contains: Zn, 2.58\%; Mn, $1.43 \%$; Cu, 0.90\%; Co, 0.18\%; Met, $8.21 \%$; Lys, $3.8 \%$.

${ }^{3}$ Contents per kilogram: vitamin A $(1,650,000 \mathrm{IU})$, vitamin $\mathrm{D}_{3}$ (517,000 IU), vitamin E (8,800 IU), biotin (352 mg), Ca (15.4\%), Mn (1.0\%), Zn (8,600 mg/kg), Fe (6,000 mg/kg), Cu (1,500 mg/kg), I (250 $\mathrm{mg} / \mathrm{kg})$, and Se $(110 \mathrm{mg} / \mathrm{kg})$.

${ }^{4}$ All values except for DM are expressed on a DM basis. Percentages of $\mathrm{DM}, \mathrm{CP}, \mathrm{NDF}, \mathrm{ADF}$, and ash were analyzed values, whereas $\mathrm{Ca}$ and $\mathrm{P}$ were calculated.

1988). Steers were moved into individual metabolism stanchions $2 \mathrm{~d}$ before sample collection in each period.

\section{Sample Collection and Preparation}

Diets were weighed out daily and fed to steers on an individual basis to allow for ad libitum intake. Samples of the diet were collected at feeding and frozen $\left(-20^{\circ} \mathrm{C}\right)$ until analysis. Orts were weighed, recorded, and sampled daily for each steer. At the end of each period, diet and orts were composited by steer, subsampled, and stored frozen $\left(-20^{\circ} \mathrm{C}\right)$. Diet and orts samples were dried in a forced-air oven $\left(60^{\circ} \mathrm{C}\right)$ for $72 \mathrm{~h}$ and ground in a Wiley mill (Thomas Scientific, Swedesboro, NJ) to pass through a $1-\mathrm{mm}$ screen. On d 16 through 20 , fecal grab samples were collected twice daily at 0800 and $1700 \mathrm{~h}$, frozen $\left(-20^{\circ} \mathrm{C}\right)$, oven-dried $\left(60^{\circ} \mathrm{C}\right.$ for $\left.72 \mathrm{~h}\right)$, composited by animal within period, ground (Wiley mill, 1-mm screen), and stored at room temperature for subsequent analyses. Samples of duodenal digesta $(250 \mathrm{~mL})$ were 
collected every $6 \mathrm{~h}$ on d $16(0200,0800,1400$, and 2000 $\mathrm{h})$, on d $17(0400,1000,1600$, and $2400 \mathrm{~h})$, and on d 18 $(0600,1200,1800$, and $2400 \mathrm{~h})$ to represent every $2 \mathrm{~h}$ over a 24 -h time period. Samples were frozen immediately, lyophilized, ground with a coffee grinder (Black \& Decker SmartGrind CBG5 Blades Grinder, Applica Consumer Products, Miramar, FL), and composited by steer within period until further laboratory analyses.

Ruminal kinetics were evaluated on d 19 and 20 . At $0800 \mathrm{~h}$ on d 19 of each period, a $200-\mathrm{mL}$ solution containing cobalt EDTA was immediately pulse-dosed before the feeding via the ruminal cannula as a fluid dilution marker for determination of fluid passage rate $\left(\mathrm{K}_{\mathrm{f}}\right)$. Samples of ruminal fluid $(50 \mathrm{~mL})$ were collected from the ventral sac of each steer by using a suction strainer before dosing $(0 \mathrm{~h})$ and at $3,6,9,12,18$, and $24 \mathrm{~h}$ after dosing to determine VFA, $\mathrm{NH}_{3}-\mathrm{N}$, and cobalt concentrations. Immediately after straining the ruminal fluid, $\mathrm{pH}$ was determined with a portable $\mathrm{pH}$ meter (HI 9024, Hanna Instruments, Ann Arbor, MI) and combination electrode. A portion of this strained ruminal fluid $(8 \mathrm{~mL}$ ) was then acidified with $25 \%$ (wt/vol) metaphosphoric acid $(2 \mathrm{~mL})$ and frozen $\left(-20^{\circ} \mathrm{C}\right)$ for analysis of VFA. A second aliquot of strained ruminal fluid (10 $\mathrm{mL}$ ) was acidified with $0.5 \mathrm{~mL}$ of $6 \mathrm{~N} \mathrm{HCl}$ and frozen $\left(-20^{\circ} \mathrm{C}\right)$ for $\mathrm{NH}_{3}-\mathrm{N}$ analysis. A third aliquot of strained ruminal fluid $(10 \mathrm{~mL})$ was frozen $\left(-20^{\circ} \mathrm{C}\right)$ immediately after collection for determination of cobalt concentration.

Total ruminal contents were evacuated on $\mathrm{d} 21$. Ruminal contents were weighed, mixed thoroughly, and subsampled in duplicate (approximately $1 \mathrm{~kg}$, as-is basis). Following sampling, the ruminal contents of control steers were mixed, subdivided, and placed into the rumen of all steers to minimize carryover effects of yeast and P169 from period to period (Beauchemin et al., 2003). About $1 \mathrm{~kg}$ of ruminal contents was mixed with $1 \mathrm{~L}$ of a formaldehyde solution $(100 \mathrm{~mL}$ of $37 \%$ formaldehyde and $9 \mathrm{~g}$ of $\mathrm{NaCl}$ in $900 \mathrm{~mL}$ of $\mathrm{dH}_{2} \mathrm{O}$ ) and stored frozen $\left(-20^{\circ} \mathrm{C}\right)$ for subsequent bacterial isolation to determine the purine: $\mathrm{N}$ ratio in the ruminal bacteria. Concurrently, samples of ruminal contents were weighed, dried $\left(60^{\circ} \mathrm{C}, 72 \mathrm{~h}\right)$, ground (1-mm screen), and stored at room temperature for further analyses.

Blood samples were collected via coccygeal venipuncture at the time of ruminal sample collection $(0$ and 3 h). After blood collection in 10-mL Vacutainer tubes containing EDTA (Becton Dickinson, Franklin Lakes, NJ), blood was stored on ice, transported to the laboratory, and centrifuged at $1,200 \times \mathrm{g}$ for $15 \mathrm{~min}$ at $4^{\circ} \mathrm{C}$. Plasma was harvested and stored at $-20^{\circ} \mathrm{C}$ until subsequent analysis of concentrations of plasma glucose and insulin.

\section{Laboratory Methods}

Feed, orts, ruminal contents, duodenal digesta, and fecal samples were analyzed for DM, ash, NDF, ADF, $\mathrm{N}$, and acid detergent insoluble ash (ADIA). Dry matter for all samples was determined by oven-drying at $105^{\circ} \mathrm{C}$ for $24 \mathrm{~h}$ (method 4.1.06, AOAC, 1997). Ash content was determined by ashing samples at $550^{\circ} \mathrm{C}$ for $8 \mathrm{~h}$ in a muffle furnace (method 4.1.10, AOAC, 1997). Nitrogen was determined by using a Leco NS-2000 Nitrogen Analyzer (Leco Corporation, St. Joseph, MI). Neutral detergent fiber and $\mathrm{ADF}$ were determined by using the method of Goering and Van Soest (1970). Acid detergent insoluble ash was determined as the residue following complete combustion of the ADF residue (Van Soest et al., 1991).

Duodenal and fecal samples were analyzed for $\mathrm{Cr}$ concentrations to determine digesta flow throughout the gastrointestinal tract. The samples were prepared by using the procedure of Williams et al. (1962), and Cr levels were determined by an inductively coupled plasma analyzer (ICP Spectro Analytical Instruments, Fitchburg, MA). Ruminal samples mixed with formaldehyde were thawed in a refrigerator at $4^{\circ} \mathrm{C}$ for at least $24 \mathrm{~h}$, mixed, homogenized in a blender (Waring Products, New Hartford, CT) at high speed for 2 min, and strained through 2 layers of cheesecloth to remove large particles. The liquid fraction was centrifuged $(1,500 \times$ g; $10 \mathrm{~min}, 4^{\circ} \mathrm{C}$ ) in 250 -mL bottles to separate protozoa and feed particles from bacteria. The supernatant was decanted into additional $250-\mathrm{mL}$ bottles and bacteria was pelleted by centrifuging $\left(20,000 \times g ; 20 \mathrm{~min}, 4^{\circ} \mathrm{C}\right)$. The supernatant was decanted and discarded, leaving only the bacterial pellet. The bacterial pellet was resuspended with approximately $100 \mathrm{~mL}$ of $0.9 \%$ (wt/vol) $\mathrm{NaCl}$ and centrifuged $\left(20,000 \times g ; 20 \mathrm{~min}, 4^{\circ} \mathrm{C}\right)$. Triplicate bottles of bacteria from each steer and period were combined into a single sample and rinsed 3 times. Bacteria were then frozen $\left(-20^{\circ} \mathrm{C}\right)$, lyophilized, and ground with a mortar and pestle before analysis. Duodenal and bacterial isolates were analyzed for $\mathrm{N}$ (as previously described) and purine concentrations to determine microbial protein flow following a modified Zinn and Owens (1986) procedure that used a diluted $\mathrm{HClO}_{4}$ to hydrolyze the material containing purines. The $\mathrm{HClO}_{4}$ $(70 \%)$ was diluted with water to prepare a solution of $2 \mathrm{M} \mathrm{HClO}_{4}$ for the extraction procedure.

For determination of VFA concentrations, acidified ruminal fluid samples were thawed at room temperature and centrifuged to pellet solids (10 min at 3,000 $\times$ g). Samples of the supernatant $(2 \mathrm{~mL})$ were filtered through a $0.2-\mu \mathrm{m}$ filter directly into $2-\mathrm{mL}$ HPLC autosampler vials and capped. Samples were analyzed by HPLC using a Waters 2690 instrument with a 2410 
refractive index detector (Waters Corporation, Milford,

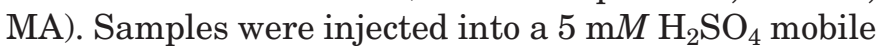
phase heated to $60^{\circ} \mathrm{C}$ and separated on a Bio-Rad HPX87H column (Bio-Rad Laboratories Inc., Hercules, CA). Peak areas were used to determine compound concentration by comparison with external standards. The external standard solution was prepared volumetrically with glucose, lactic acid, succinic acid, butyric acid, propionic acid, and glacial acetic acid. Ruminal $\mathrm{NH}_{3}-\mathrm{N}$ concentration was determined colorimetrically by using a Beckman DU 530 spectrophotometer (Beckman Instruments Inc., Fullerton, CA; Broderick and Kang, 1980). Nonacidified ruminal fluid samples were thawed and centrifuged at $30,000 \times g$ for $20 \mathrm{~min}$, and the supernatant fluid was analyzed for cobalt concentration (atomic absorption spectroscopy, model 4000, PerkinElmer, Norwalk, CT; with an air plus acetylene flame).

Plasma concentrations of glucose were determined by using colorimetric glucose kits (Thermo Electron Corporation, Louisville, CO) as described previously (Aleman et al., 2007). Plasma concentrations of insulin were determined by using a solid-phase insulin RIA kit (Micromedia Insulin Kit, ICN Biomedicals Inc., Costa Mesa, CA) as described previously (Francisco et al., 2002). All samples were analyzed in a single assay with an intraassay coefficient of variation of $<5 \%$.

\section{Calculations and Statistical Analyses}

Apparent ruminal digestibility of nutrients was calculated by subtracting nutrient flow at the duodenum from nutrients consumed, divided by nutrients consumed. Particulate passage was determined by dividing daily ADIA intake by ADIA ruminal fill. Liquid dilution rates were determined by using the REG procedure of SAS (version 8, SAS Institute Inc., Cary, NC) to regress the natural logarithms of cobalt concentration against time (Grovum and Williams, 1973). The resulting slopes represented liquid dilution rates. Ruminal liquid turnover time was calculated as the inverse of the dilution rate. Flow $(\mathrm{g} / \mathrm{d})$ of bacterial $\mathrm{N}$ at the duodenum was estimated by dividing the average bacterial $\mathrm{N}$ :purine ratio of harvested bacteria by the $\mathrm{N}$ :purine ratio of the duodenal digesta and multiplying the quotient by the daily $\mathrm{N}$ flow at the duodenum (Erasmus et al., 1992), and was used to describe the effects of P169, XPY, or their combination on nutrient digestibility and microbial protein synthesis in the rumen and the resulting nutrient supply to the small intestine.

Feed intake, digestibility, duodenal flow, and ruminal kinetic data were analyzed as a replicated completely random design with a $2 \times 2$ factorial arrangement of treatments by using the MIXED procedure of SAS. Ruminal $\mathrm{pH}, \mathrm{VFA}, \mathrm{NH}_{3}$, plasma glucose, and insulin were analyzed as a completely random design with a $2 \times$ 2 factorial arrangement of treatments with repeated measures over time. The statistical model included fixed effects for P169, XPY, P169 $\times$ XPY, time, and the 2 - and 3-way treatment $\times$ time interactions, with steer and period as random effects. The repeated subject was animal nested within treatment. The covariance structure that provided the best fit to the data was autoregressive lag $=1$. If an interaction was significant, simple effects were analyzed by using the slice option for the LSMEANS statement. The level of significance was set at $P<0.05$ and at $P<0.10$ for a trend.

\section{RESULTS}

\section{Intake, Duodenal Flow, and Digestibility}

There were no $(P \geq 0.46) \mathrm{P} 169 \times \mathrm{XPY}$ interactions for $\mathrm{OM}, \mathrm{NDF}$, and $\mathrm{ADF}$ intake, and no effects $(P \geq 0.46)$ of feeding P169 on OM, NDF, and ADF intakes; fecal output; or apparent total tract digestibility of OM, NDF, and ADF (Table 2). Feeding XPY alone tended $(P=$ 0.06 ) to decrease $\mathrm{OM}$ and ADF intake and decreased $(P<0.05) \mathrm{NDF}$ intake. There tended $(P \leq 0.09)$ to be $\mathrm{P} 169 \times \mathrm{XPY}$ interactions for fecal OM, NDF, and ADF output and for OM, NDF, and ADF total tract digestibility; XPY decreased fecal output in control steers but not in steers fed P169, whereas P169 increased fecal output of OM and NDF in XPY-fed steers (Table 2). This resulted in tendencies $(P \leq 0.08)$ toward increased total tract digestibilities of $\mathrm{OM}, \mathrm{NDF}$, and $\mathrm{ADF}$ when XPY was fed in the absence of P169, and the increased total tract digestibilities in steers fed XPY alone did not significantly differ from those of steers fed P169 alone (Table 2). There were no P $169 \times \mathrm{XPY}$ interactions $(P \geq 0.23)$ or main treatment effects $(P \geq 0.21)$ for duodenal nutrient flow or ruminal digestibility of OM, NDF, and ADF (Table 2).

\section{N Intake, Duodenal N Flow, and Microbial Efficiency}

There were no effects $(P \geq 0.41)$ of feeding P169 on $\mathrm{N}$ intake, duodenal $\mathrm{N}$ flow, microbial efficiency, $\mathrm{N}$ digestibility, or fecal output (Table 3). Feeding XPY tended $(P=0.07)$ to decrease $\mathrm{N}$ intake; however, XPY had no effect $(P \geq 0.10)$ on duodenal $\mathrm{N}$ flow, microbial $\mathrm{N}$, fecal output, or apparent total tract digestibility of $\mathrm{N}$ (Table 3).

\section{Ruminal Kinetics, Fill, and VFA}

Liquid dilution and particulate passage rates were not affected $(P \geq 0.27)$ by P169, XPY, or their interaction (Table 4). Ruminal DM fill (contents) tended $(P=0.07)$ to be decreased by XPY, and ruminal fluid fill (volume) 
Table 2. Effects of feeding Propionibacteria, yeast, or both on intake, fecal output, total tract digestibility, duodenal flow, and ruminal digestibility in steers fed a sorghum silage-based TMR ${ }^{1}$

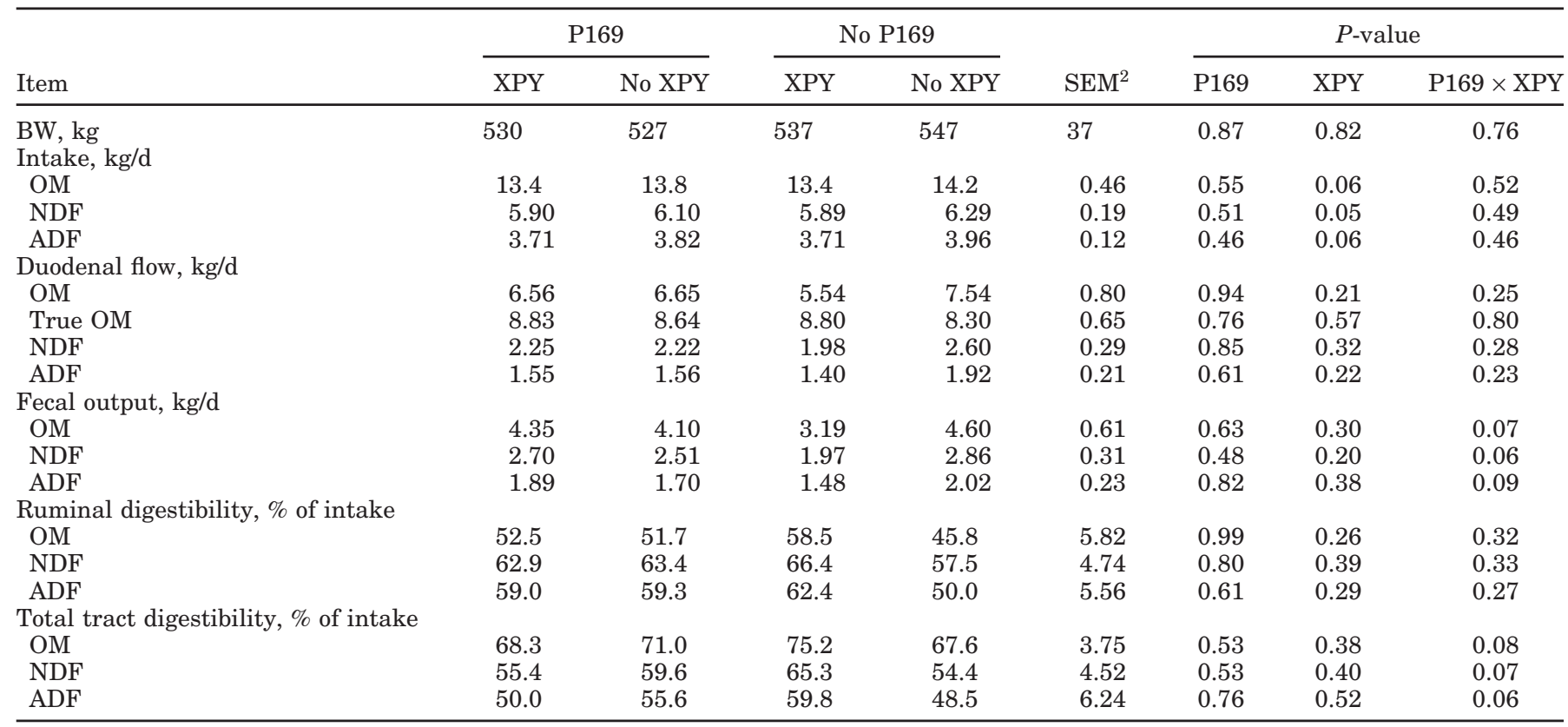

${ }^{1}$ Diets: no yeast culture or propionibacteria (control = sorghum silage-based TMR); XPY = control plus Diamond V-XP Yeast Culture (Diamond V Mills Inc., Cedar Rapids, IA; 56 g/steer per d); P169, control plus Propionibacterium strain P169 (6 × $10^{11}$ cfu/steer per d); P169 + XPY $=$ control plus P169 and XPY (at $6 \times 10^{11} \mathrm{cfu} /$ steer per d and $56 \mathrm{~g} /$ steer per d, respectively).

${ }^{2} \mathrm{n}=6$.

was decreased $(P=0.05)$ in steers fed XPY vs. no XPY. There were no effects of P169 $(P=0.84)$ or XPY $(P=$ 0.55 ) on ruminal turnover time (Table 4 ).

Ruminal pH was influenced by time $(P<0.001)$ and the time $\times \mathrm{P} 169 \times \mathrm{XPY}$ interaction $(P<0.01$; Figure 1$)$, but not by P169, XPY, or their interaction $(P \geq 0.47$; Table 4). In general, ruminal $\mathrm{pH}$ decreased with time after feeding, and the lowest $(6.08 \pm 0.08 ; P<0.05) \mathrm{pH}$ was observed at $12 \mathrm{~h}$ in all steers (Figure 1 ). This decline was more evident in steers receiving P169 + XPY than those fed P169 without XPY. Ruminal $\mathrm{NH}_{3}-\mathrm{N}$ concentration was not influenced $(P \geq 0.13)$ by feeding P169 or XPY, or by their interaction (Table 4). However, ruminal $\mathrm{NH}_{3}-\mathrm{N}$ was influenced $(P<0.001)$ by time of feeding (data not shown). Ruminal $\mathrm{NH}_{3}-\mathrm{N}$ concentrations gradually decreased between time 0 and $9 \mathrm{~h}$ postfeeding. Thereafter, a significant increase $(P<0.05)$ in ruminal $\mathrm{NH}_{3}-\mathrm{N}$ was observed between 12 and $24 \mathrm{~h}$

Table 3. Effect of feeding Propionibacteria, yeast, or both on $\mathrm{N}$ intake, duodenal $\mathrm{N}$ flow and $\mathrm{N}$ digestibility in steers fed a sorghum silagebased TMR ${ }^{1}$

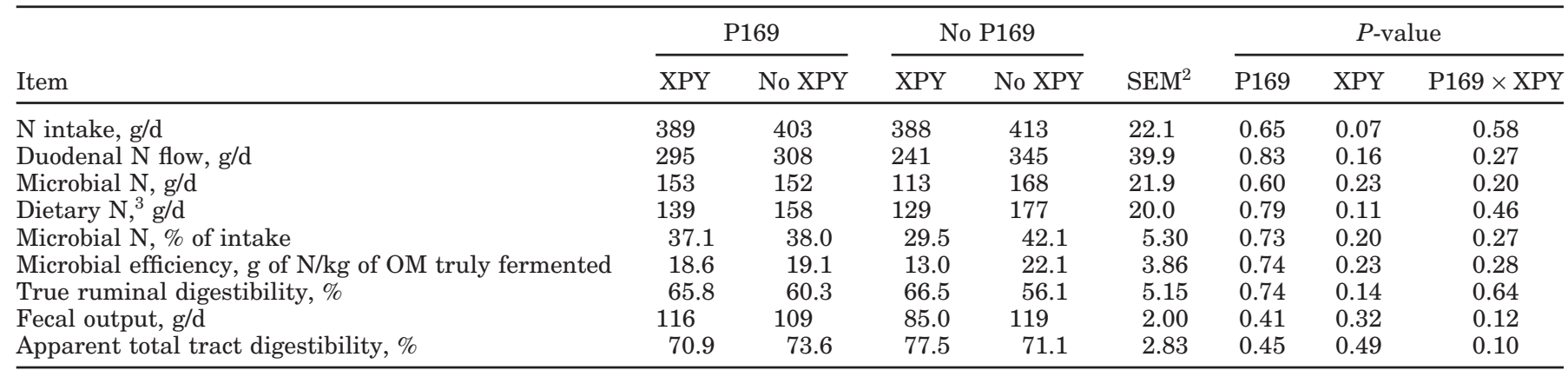

${ }^{1}$ Diets: no yeast culture or propionibacteria (control = sorghum silage-based TMR); XPY = control plus Diamond V-XP Yeast Culture (Diamond V Mills Inc., Cedar Rapids, IA; 56 g/steer per d); P169, control plus Propionibacterium strain P169 (6 $\times 10^{11}$ cfu/steer per d); P169 $+\mathrm{XPY}=$ control plus P169 and XPY (at $6 \times 10^{11} \mathrm{cfu} /$ steer per d and $56 \mathrm{~g} /$ steer per d, respectively).

${ }^{2} \mathrm{n}=6$.

${ }^{3}$ Contains endogenous and $\mathrm{NH}_{3}-\mathrm{N}$. 
Table 4. Effect of feeding Propionibacteria, yeast, or both on ruminal kinetics, fill, and proportions of VFA in steers fed a sorghum silagebased TMR ${ }^{1}$

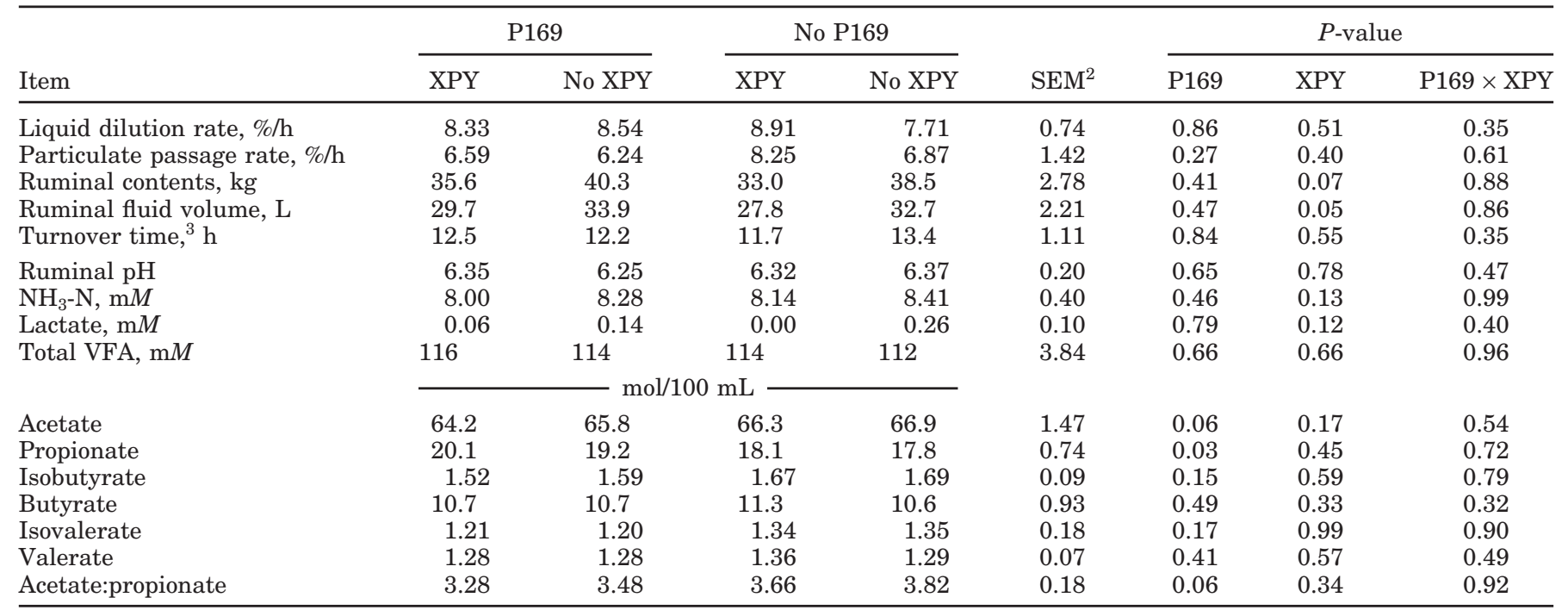

${ }^{1}$ Diets: no yeast culture or propionibacteria (control = sorghum silage-based TMR); XPY = control plus Diamond V-XP Yeast Culture (Diamond V Mills Inc., Cedar Rapids, IA; $56 \mathrm{~g} / \mathrm{steer}$ per d); P169 = control plus Propionibacterium strain P169 $\left(6 \times 10^{11} \mathrm{cfu} / \mathrm{steer}\right.$ per d); $\mathrm{P} 169+\mathrm{XPY}=$ control plus P169 and XPY $\left(\right.$ at $6 \times 10^{11} \mathrm{cfu} /$ steer per $\mathrm{d}$ and $56 \mathrm{~g} /$ steer per $\mathrm{d}$, respectively).

${ }^{2} \mathrm{n}=6$.

${ }^{3}$ Turnover time $=1$ /liquid dilution rate.

postfeeding. Ruminal concentrations of lactate were low, and most samples were below the level of detection (0.01 mM; Table 4).

Total VFA concentration and proportions of individual VFA in the rumen are shown in Table 4. There was no effect of feeding P169 or XPY $(P=0.66)$, of their interaction $(P=0.96)$, or of their interaction with time $(P=0.19)$ on total concentrations of VFA. However, as expected, time after feeding influenced $(P<0.001)$ concentrations of total VFA (data not shown). In general, increases in VFA were observed between 0 and $9 \mathrm{~h}$ postfeeding, but no significant changes occurred between 12 and $24 \mathrm{~h}$ postfeeding. Feeding P169 tended $(P=0.06)$ to decrease the proportion of ruminal acetate and increased $(9.5 \% ; P=0.05)$ the proportion of ruminal propionate compared with steers not fed P169 (Table 4). In addition, the ratio of acetate:propionate tended $(P=0.06 ; 10.7 \%)$ to be lower for steers fed P169. Dietary treatments did not affect $(P \geq 0.15)$ the proportions of isobutyrate, butyrate, isovalerate, or valerate.

\section{Plasma Glucose and Insulin}

Plasma glucose concentration was not affected $(P \geq$ 0.32 ) by feeding P169 or XPY, by time $(P=0.35)$, or by their interaction $(P=0.73)$. Plasma glucose concentrations in steers fed the control, XPY, P169, and P169+ XPY averaged 86.7, 81.2, 82.2, and $79.9 \pm 3.8 \mathrm{mg} / 100$ $\mathrm{mL}$, respectively. Similarly, plasma insulin concentra- tion was not affected $(P=0.39)$ by feeding $\mathrm{P} 169$ or XPY, by time $(P=0.14)$, or by the time $\times$ P169 $\times$ XPY interaction $(P=0.73)$. Plasma insulin concentration in steers fed the control, XPY, P169, and P169 + XPY averaged $1.36,0.92,1.35$, and $1.41 \pm 0.27 \mathrm{ng} / \mathrm{mL}$, respectively.

\section{DISCUSSION}

In general, the mode of action for supplemental directly fed microbials varies based on the type and substrate used, the physiological condition of the animal (e.g., growth, stage of lactation), the feeding strategy, and the forage:concentrate ratio (Wallace, 1994). In the present experiment, feeding XPY without P169 tended to decrease $\mathrm{OM}, \mathrm{NDF}$, and $\mathrm{ADF}$ intake, whereas feeding $\mathrm{P} 169$ did not affect OM, NDF, and ADF intake. In earlylactation dairy cows, feeding P169 decreased DMI/kg of BW (Francisco et al., 2002), and intraruminal propionate infusion decreased DMI (Oba and Allen, 2003). Although Baile (1971) proposed that propionate receptors in the ruminal region might function to control feed intake, the specific effects of propionate on regulating DMI remain unclear (Allen, 2000). Propionate is a stimulant of insulin secretion in cattle, which may indirectly influence appetite (Bines and Hart, 1984; Aleman et al., 2007); thus, a lack of insulin response to feeding P169 in the present study may have contributed 

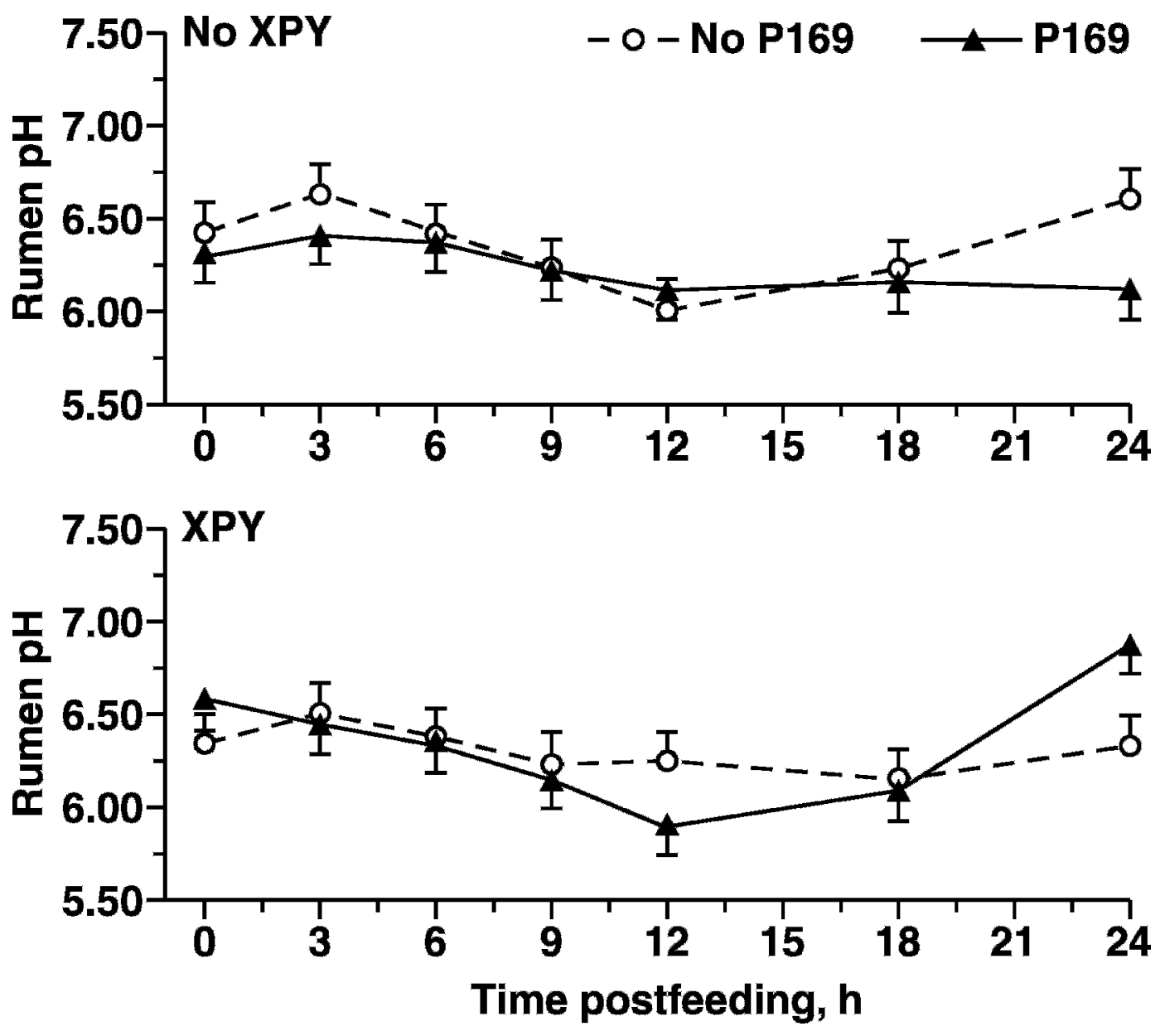

Figure 1. Effect of feeding Propionibacterium strain P169 (P169), Diamond V-XP Yeast (XPY; Diamond V Mills Inc., Cedar Rapids, IA), or both on ruminal $\mathrm{pH}$ of steers fed a sorghum silage-based TMR. Ruminal $\mathrm{pH}$ resulted in a P169 $\times \mathrm{XPY} \times$ time interaction $(P<0.01)$ for steers. Top panel $=$ ruminal $\mathrm{pH}$ of steers fed P169 $(\mathrm{n}=6)$ or no P169 $(\mathrm{n}=6)$ in the absence of XPY. Bottom panel $=$ ruminal $\mathrm{pH}$ of steers fed P169 or no P169 in the presence of XPY.

to the lack of change in nutrient intake even though ruminal propionate was increased.

Intake of N, OM, NDF, and ADF decreased with feeding XPY in the present study. Because BW was not significantly affected by XPY, it is possible that efficiency may have increased with added XPY. Studies (Swartz et al., 1994; Kung et al., 1997) in lactating dairy cows have reported no effect of feeding live yeast products on DMI, although Harris et al. (1992) reported lower DMI in early to mid lactation when cows were fed yeast culture. Wohlt et al. (1991) reported that cows fed live yeast ( $S$. cerevisiae) produced more milk because of higher feed intake during early lactation. It is clear that the response to feeding yeast products on DMI has not been consistent (reviewed in Martin and Nisbet, 1992; Beauchemin et al., 2006), and may be due to the type of yeast product (e.g., live or inactive cultures) or level of stress on the animal (Arambel and
Kent, 1990). Erasmus et al. (1992) reported that a supplemental yeast culture increased DMI when a 75-d adaptation period was used to eliminate any carryover effects. Thus, the adaptation time used for supplement feeding in the present study may not have been long enough to elicit an effect. Alternatively, it could be that the control TMR, typical of diets used for lactating cows, provided adequate nutrients for maximum metabolism such that supplementation of P169 or XPY did not result in increased intake in the mature steers used in the present experiment. Thus, use of steers as a model to study rumen function in lactating dairy cows may not be ideal because of the differences in intake and subsequent flow of nutrients.

Increased bacterial numbers that lead to greater lactate utilization and increased fiber digestion in the rumen has been one of the most consistently reported effects in animals fed yeast culture (reviewed in 
Beauchemin et al., 2006). Wiedmeier et al. (1987) showed with nonlactating cows that feeding $S$. cerevisiae increased total tract digestibility of $\mathrm{CP}$ and hemicellulose but not DM or ADF. In the present study, XPY fed without P169 tended to increase total tract digestibility of OM, NDF, and ADF. Although not significant, ruminal digestibility followed a similar numeric trend. In continuous culture, Miller-Webster et al. (2002), testing 2 yeast products, reported a tendency for increased $\mathrm{DM}$ digestibility with no effect on digestibility of NDF, $\mathrm{ADF}$, or NSC.

In the present experiment, XPY, P169, or their combination did not affect microbial $\mathrm{N}$ flow to the duodenum or microbial efficiency. Erasmus et al. (1992) fed $10 \mathrm{~g} /$ $\mathrm{d}$ of yeast culture to lactating dairy cows consuming a $35 \%$ forage diet that contained $25 \%$ wheat straw on a $\mathrm{DM}$ basis and reported a trend for increased flow of AA to the duodenum compared with controls with no effect on liquid dilution rate or turnover time. However, live yeast culture had no effect on flow of AA to the duodenum in lactating dairy cows fed a corn silage TMR (Putnam et al., 1997). In the present experiment using a sorghum silage-based TMR, feeding P169, XPY, or their combination also did not affect particulate passage rate, liquid dilution rate, or turnover time. Additional research will be required to ascertain the interaction between type of diet (i.e., forage and concentrate type and amount) and feeding supplemental P169, XPY, or both on passage rate and microbial efficiency.

Ruminal concentration of $\mathrm{NH}_{3}-\mathrm{N}$ was not affected by dietary treatment, but was affected by sampling time in the present study. In comparison, Erasmus et al. (1992) reported decreased ruminal $\mathrm{NH}_{3}$ concentrations with yeast supplementation. Although many cellulolytic bacteria require and use $\mathrm{NH}_{3}$ as their only source of $\mathrm{N}$ (Russell et al., 1992), high concentrations of ruminal $\mathrm{NH}_{3}$ do not always imply the most efficient growth of bacteria. Horn and McCollum (1987) suggested that ruminal $\mathrm{NH}_{3}$ concentrations are more indicative of the balance between ruminally available energy and degradable protein than efficiency of microbial growth.

In the present study, ruminal $\mathrm{pH}$ averaged across sampling time did not differ among treatments but decreased with time after feeding, with the nadir $\mathrm{pH}$ observed at 12 h. Similarly, Ghorbani et al. (2002) reported that ruminal $\mathrm{pH}$ was not affected by feeding supplemental microbes (i.e., Propionibacterium strain P15 and P15 plus Enterococcus faecium EF212) compared with controls, and the lowest $\mathrm{pH}$ values occurred between 11 to $13 \mathrm{~h}$ after feeding.

Neither P169 nor XPY influenced total VFA concentration or molar percentages of isobutyrate, butyrate, isovalerate, or valerate. However, steers fed P169 had
9.5\% greater ruminal propionate proportions compared with steers not fed P169. As a result of a greater proportion of propionate and a tendency for a lower proportion of acetate, the acetate:propionate ratio was $10.7 \%$ lower in steers fed P169. Previously, feeding Propionibacterium to lactating cows increased ruminal proportions of propionate (Stein et al., 2006). Akay and Dado (2001) reported that total VFA, propionate, acetate, butyrate, and valerate were increased above those of control animals at all levels $\left(0,10^{3}, 10^{6}\right.$, and $\left.10^{9} \mathrm{cfu} / \mathrm{mL}\right)$ of inclusion of Propionibacterium P5 in vitro. Therefore, based on results of the present and previous experiments, feeding a propionate-producing bacteria has the potential to increase ruminal proportions of propionate.

Based on the fact that propionate is the major glucogenic precursor, an increase in propionate concentrations signifies an increase in energy for growth or production. Supplementing the diet with P169, XPY, or both in the present study did not increase glucose or insulin concentrations. Previously, feeding P169 increased the plasma glucose concentration in primiparous cows but had no effect in multiparous cows during early and mid lactation (Francisco et al., 2002; Aleman et al., 2007). However, feeding live (Putnam et al., 1997) yeast had no effect on concentrations of plasma glucose and insulin in early-lactation dairy cows. In cattle (Oba and Allen, 2003) and sheep (Sano et al., 1993), feeding sources of propionate or an infusion of propionate at large enough amounts and for durations long enough to increase levels of glucose and insulin showed transient increases in glucose and insulin concentrations. In addition, insulin responses to propionate infusion depended on the level of nutrients fed to nonlactating, nonpregnant mature ewes (Quigley and Heitmann, 1991). Thus, lower feed intake in XPY-fed vs. control steers might have influenced the glucose and insulin response to feeding P169, XPY, or both in the present study.

\section{CONCLUSIONS}

Results from the present experiment indicate that feeding steers P169 altered ruminal metabolism toward increased propionate without affecting feed intake, duodenal flow, microbial nitrogen synthesis, or ruminal kinetics. Feeding XPY without P169 decreased OM, NDF, and ADF intake. The XPY fed without P169 tended to improve total tract digestibilities of OM, $\mathrm{ADF}$, and NDF. Additional studies are warranted to determine the effects of feeding P169, XPY, or their combination on ruminal kinetics and nutrient digestibilities in cattle of different physiological statuses, such as negative energy balance. 


\section{ACKNOWLEDGMENTS}

The authors thank the W. K. Kellogg Foundation Africa Study Grants Program for financial support of K. Lehloenya; the crew of the Oklahoma State University Nutrition Physiology Research Barn for care and management of the steers; Joan Summers, Dustin Allen, and Shaban Janloo for assistance with laboratory analyses; the Ruminant Nutrition Laboratory at the University of Nebraska for purine analysis, and Mark Payton (Oklahoma State University) for statistical advice.

\section{REFERENCES}

Akay, V., and R. G. Dado. 2001. Effects of Propionibacterium strain P5 on in-vitro volatile fatty acids production and digestibility of fiber and starch. Turk. J. Vet. Anim. Sci. 25:635-642.

Aleman, M. M., D. R. Stein, D. T. Allen, E. Perry, K. V. Lehloenya, T. G. Rehberger, K. J. Mertz, D. A. Jones, and L. J. Spicer. 2007. Effect of feeding two levels of propionibacteria to dairy cows on plasma hormones and metabolites. J. Dairy Res. 74:146-153.

Allen, M. S. 2000. Effects of diet on short-term regulation of feed intake by lactating dairy cattle. J. Dairy Sci. 83:1598-1624.

AOAC. 1997. Official Methods of Analysis. 16th ed. K. Helrich, ed. Assoc. Off. Anal. Chem., Arlington, VA.

Arambel, M. J., and B. A. Kent. 1990. Effect of yeast culture on nutrient digestibility and milk yield response in early to midlactation dairy cows. J. Dairy Sci. 73:1560-1563.

Baile, C. 1971. Metabolites as feedbacks for control of feed intake receptor sites in goats and sheep. Physiol. Behav. 7:819-826.

Beauchemin, K. A., C. R. Krehbiel, and C. J. Newbold. 2006. Feed enzymes and direct-fed microbials in ruminant nutrition. Pages 251-284 in Biology of Nutrition in Growing Animals. R. Mosenthin, J. Zentek, and T. Zehrowska, ed. Elsevier Limited, Philadelphia, PA.

Beauchemin, K. A., W. Z. Yang, D. P. Morgavi, G. R. Ghorbani, W. Kautz, and J. A. Z. Leedle. 2003. Effects of bacterial direct fed microbials and yeast on site and extent of digestion, blood chemistry, and subclinical ruminal acidosis in feedlot cattle. J. Anim. Sci. 81:1628-1640

Bines, J. A., and J. C. Hart. 1984. The response of plasma insulin and other hormones to intraruminal infusion of VFA mixture in cattle. Can. J. Anim. Sci. 64(Suppl.):304-305.

Broderick, G. A., and J. H. Kang. 1980. Automated simultaneous determination of ammonia and total amino acids in ruminal fluid and in vitro media. J. Dairy Sci. 67:820-826.

Callaway, E. S., and S. A. Martin. 1997. Effect of Saccharomyces cerevisiae culture on ruminal bacteria that utilize lactate and digest cellulose. J. Dairy Sci. 80:2035-2044.

Christensen, J. O., R. R. Grummer, F. E. Rasmussen, and S. J. Bertics. 1997. Effect of method of delivery of propylene glycol on plasma metabolites of feed-restricted cattle. J. Dairy Sci. 80:563-568.

Drackley, J. K., T. R. Overton, and G. N. Douglas. 2001. Adaptations of glucose and long-chain fatty acid metabolism in liver of dairy cows during the periparturient period. J. Dairy Sci. 84:100-112.

Erasmus, L. J., P. M. Botha, and A. Kistner. 1992. Effect of yeast culture supplement on production, rumen fermentation, and duodenal nitrogen flow in dairy cows. J. Dairy Sci. 75:3056-3065.

Francisco, C. C., C. S. Chamberlain, D. N. Waldner, R. P. Wettemann, and L. J. Spicer. 2002. Propionibacteria fed to dairy cows: Effects on energy balance, plasma metabolites and hormones, and reproduction. J. Dairy Sci. 85:1738-1751.

Gerloff, B. J. 2000. Dry cow management for the prevention of ketosis and fatty liver in dairy cows. Vet. Clin. North Am. Food Anim. Pract. 16:283-292.

Ghorbani, G. R., D. P. Morgavi, K. A. Beauchemin, and J. A. Z. Leedle. 2002. Effects of bacterial direct-fed microbials on ruminal fermentation, blood variables, and the microbial populations of feedlot cattle. J. Anim. Sci. 80:1977-1986.
Goering, H. K., and P. J. Van Soest. 1970. Forage Fiber Analysis (Apparatus, Reagents, Procedures, and Applications). Agric. Handbook No. 379. ARS, USDA, Washington, DC.

Grovum, W. L., and V. J. Williams. 1973. Rate of passage of digesta in sheep. 1. The effect of level of food intake on marker retention times along the small and large intestines. Br. J. Nutr. 29:13-21.

Grummer, R. R., J. C. Winkler, S. J. Bertics, and V. A. Studer. 1994 Effect of propylene glycol dosage during feed restriction on metabolites in blood of prepartum Holstein heifers. J. Dairy Sci. 77:3618-3623.

Harris, B., Jr., D. E. Dorminey, W. A. Smith, H. H. Van Horn, and C. J. Wilcox. 1992. Effects of feather meal a two protein concentrations and yeast culture on production parameters in lactating dairy cows. J. Dairy Sci. 75:3524-3530.

Horn, G. W., and F. T. McCollum. 1987. Energy supplementation of grazing ruminants. Pages 125-136 in Proc. Grazing Livest. Nutr. Conf., Jackson, WY. Univ. Wyoming, Jackson Hole.

Kung, L., E. M. Kreck, R. S. Tung, A. O. Hession, A. C. Shepherd, M. A. Cohen, H. E. Swain, and J. A. Z. Leedle. 1997. Effects of a live yeast culture and enzyme on in vitro ruminal fermentation and milk production. J. Dairy Sci. 80:2045-2051.

Martin, S. A., and D. J. Nisbet. 1992. Effect of direct fed microbials on rumen microbial fermentation. J. Dairy Sci. 75:1736-1744.

Merchen, N. R. 1988. Digestion, absorption, and excretion in ruminants. Pages 172-209 in The Ruminant Animal: Digestive Physiology and Nutrition. D. C. Church, ed. Prentice-Hall, Englewood Cliffs, NJ.

Miller-Webster, T., W. H. Hoover, M. Holt, and J. E. Nocek. 2002. Influence of yeast culture on ruminal microbial metabolism in continuous culture. J. Dairy Sci. 85:2009-2014.

Oba, M., and M. S. Allen. 2003. Intraruminal infusion of propionate alters feeding behavior and decreases energy intake of lactating dairy cows. J. Nutr. 133:1094-1099.

Putnam, D. E., C. G. Schwab, M. T. Socha, N. L. Whitehouse, N. A Kierstead, and B. D. Garthwaite. 1997. Effect of yeast culture in the diets of early lactation dairy cows on ruminal fermentation and passage of nitrogen fractions and amino acids to the small intestine. J. Dairy Sci. 80:374-384.

Quigley, J. D., and R. N. Heitmann. 1991. Effects of propionate infusion and dietary energy on dry matter intake in sheep. J. Anim. Sci. 69:1178-1187.

Russell, J. B., J. D. O'Conner, D. G. Fox, P. J. Van Soest, and C. J. Sniffen. 1992. A net carbohydrate and protein system for evaluating cattle diets. I. Ruminal fermentation. J. Anim. Sci. 70:3551-3561.

Sano, H., N. Hattori, Y. Todome, J. Tsuroka, H. Takahashi, and Y. Tereshima. 1993. Plasma insulin and glucagon responses to intravenous infusion of propionate and their autonomic control in sheep. J. Anim. Sci. 71:3414-3422.

Schingoethe, D. J., K. N. Linke, K. F. Kalscheur, A. R. Hippen, D. R. Rennich, and I. Yoon. 2004. Feeding efficiency of mid-lactation dairy cows fed yeast culture during summer. J. Dairy Sci. $87: 4178-4181$

Seal, C. J., and C. K. Reynolds. 1993. Nutritional implications of gastrointestinal and liver metabolism in ruminants. Nutr. Res. Rev. 6:185-208.

Soder, K. J., and L. A. Holden. 1999. Dry matter intake and milk yield and composition of cows fed yeast prepartum and postpartum. J. Dairy Sci. 82:605-610.

Stein, D. R., D. T. Allen, E. B. Perry, J. C. Bruner, K. W. Gates, T. G. Rehberger, K. J. Mertz, D. A. Jones, and L. J. Spicer. 2006. Effect of feeding propionibacteria to dairy cows on milk yield, milk components, and reproduction. J. Dairy Sci. 89:111-125.

Swartz, D. L., L. D. Muller, G. W. Rogers, and G. A. Varga. 1994 Effect of yeast cultures on performance of lactating dairy cows: A field study. J. Dairy Sci. 77:3073-3080.

van Knegsel, A. T., H. van den Brand, J. Dijkstra, S. Tamminga, and B. Kemp. 2005. Effect of dietary energy source on energy balance, production, metabolic disorders and reproduction in lactating dairy cattle. Reprod. Nutr. Dev. 45:665-688.

Van Soest, P. J., J. B. Robertson, and B. A. Lewis. 1991. Methods for dietary fiber, neutral detergent fiber, and nonstarch polysac- 
charides in relation to animal nutrition. J. Dairy Sci. 44:35833597.

Wallace, R. J. 1994. Ruminal microbiology, biotechnology, and ruminant nutrition: Progress and problems. J. Anim. Sci. 72:29923003.

Wang, Z., M. L. Eastridge, and X. Qiu. 2001. Effects of forage neutral detergent fiber and yeast culture on performance of cows during early lactation. J. Dairy Sci. 84:204-212.

Wiedmeier, R. D., M. J. Arambel, and J. L. Walters. 1987. Effect of yeast culture and Aspergillus oryzae fermentation extract on ruminal characteristics and nutrient digestibility. J. Dairy Sci. 70:2063-2068.

Williams, C. H., D. J. David, and O. Iismaa. 1962. The determination of chromic oxide in faces samples by atomic absorption spectrophotometry. J. Agric. Sci. (Camb.) 59:381-385.

Wohlt, J. E., A. D. Finkelstein, and C. H. Chung. 1991. Yeast culture to improve intake, nutrient digestibility and performance by dairy cattle during early lactation. J. Dairy Sci. 74:1395-1400.

Zinn, R. A., and F. N. Owens. 1986. A rapid procedure for purine measurement and its use for estimating net ruminal protein synthesis. Can. J. Anim. Sci. 66:157-166. 